\title{
A comparison of different tending variants in beech stands by the crown thinning and from the view of their quantitative and qualitative development
}

\author{
Igor Štefančík
}

National Forest Centre - Forest Research Institute Zvolen, T. G. Masaryka 2175/22, SK - 96092 Zvolen, Slovak Republic

\begin{abstract}
Impact of tending on dvelopment of beech (Fagus sylvatica L.) pole timber stands was analysed using different variants of the free crown thinning, i.e. the original method developed in Slovakia at the end of 1950s. Four variants of this method were compared: (i) - the free crown thinning on the whole area, the method of promising trees, later the method of target trees at stand age of 58 years. (ii) - the free crown thinning on non-whole area, tending realised inside of growth space of target trees only, the method of target trees, salvage cutting on the whole area. (iii) - the free crown thinning on non-whole area, the method of promising trees (the method of target trees at stand age of 58 years) realised on circular plots with diameter $4 \mathrm{~m}$ and spacing $8 \mathrm{~m}$ (distance between centre of circular plots). (iv) - combined selective method, thinning from below and the free crown thinning by method of target trees was used by the first thinning, in next thinning only the free crown thinning on whole-area was used, method of target trees. The structure (diameter and height) of the stand, the quantitative production parameters had been observed for a period of 30 years. Small differences were found in diameter and height structure between the variant (iv) and other three ones. Comparison of quantitative production pointed out minimum differences in favour of the variant (iv) compared to the other ones. The same results were also obtained in the qualitative production, especially for selective quality (target trees).
\end{abstract}

Key words: Fagus sylvatica; crown thinning; stand structure; production; target trees

Editor: Jaroslaw Socha

\section{Introduction}

European beech (Fagus sylvatica L.) is a native tree species in Slovak forests (Vladovič 2003), and currently occupies about 33\% of the forest land (Green Report 2015). Its future proportion is expected to be $36 \%$ (Vladovič 2003). Thanks to its favourable biological and ecological characteristics (Barna et al. 2011) and high productivity (Chunyu Zhang et al. 2010; Petráš \& Mecko 2010), it has its irreplaceable position in the forests of Slovakia. In foreign countries (Germany, Denmark, Switzerland, France), attention has been paid to the knowledge of structure and development of beech stands for more than 100 years (Schädelin 1934; Badoux 1939; Pardé 1981; Utschig \& Küsters 2003). In Slovakia, systematic research began much later, only at the end of the $1950 \mathrm{~s}$ of the last century (Štefančík 1964).

In the past, greater attention has been paid to the tending of beech stands and its impacts on quantitative production (Vyskot et al. 1962; Assmann 1968; Réh 1968; Šebík 1971; Kennel 1972; Štefančík 1974, 1984; Polge 1981; Pardé 1981; Šebík \& Polák 1990; LeGoff \& Ottorini 1993; Dhôte 1997; Pretzsch 2005). Among these, different variants of low thinning (Foerster 1993;
Utschig \& Küsters 2003) and also crown thinning (Assmann 1968; Šebík \& Polák, 1990; Hoffmann 1994; Štefančík et al. 1996; Pretzsch 2005), both on the single tree or stand level (Diaconu et al. 2015), were observed and compared mutually.

In addition, there were numerous works that investigated the impact of tending on beech stands quality, or on beech wood itself (Šebík 1970; Štefančík 1975, 1976, 1981, 2014; Keller et al. 1976; Ferrand 1982; Kató \& Mülder 1983; Korpel'1988; Mlinšek \& Bakker 1990; Hein et al. 2007; 2011; Poljanec \& Kadunc 2013; Štefančík \& Bošel'a 2014). At the same way, the impact of management on the quality of beech assortments (Cameron 2002) and their resulting financial evaluation (Knoke \& Wenderoth 2001; Julien et al. 2013), or value production (Petráš et al. 2016), was observed. Consequently, Sedmáketal. (2012) proposed the mathematical model of the stem quality. Relationship between the quality of timber production and the species and structural diversity of forest stands was studied by Merganič et al. (2016). From this perspective, tending of beech stands focuses primarily on growing a sufficient number of individuals of the highest quality - the target trees (Altherr 1971; Štefančík 
1984; Kató \& Mülder 1983; Mlinšek \& Bakker 1990). These trees represent qualitative production which is of prime interest in beech stands, while ensuring a high level of value production of mature stands (Hein et al. 2007).

Although a number of site, natural and environmental factors (Vacek et al. 1996; Vacek \& Hejcman 2012; Vacek et al. 2014), and genetic properties and traits (Ducros et al. 1988; Hansen et al. 2003; Gömöry \& Paule 2011; Gömöry etal. 2013) affect the growth and development of beech stands, the methods of their management (Poleno \& Vacek et al. 2009), or the methods of their tending represented by the type and intensity of tending interventions (Assmann 1968; Šebík 1971; Štefančík 1974; LeGoff \& Ottorini 1993; Dhôte 1997; Utschig 2000; Pretzsch 2005; Tufekcioglu et al. 2005; Saje et al. 2013; Diaconu et al. 2015) remain one of the most important factors.

We can state that knowledge from long-term investigated experiments abroad (Pretzsch et al. 2014) and in Slovakia (Štefančík 2015) has been summarized up to now. Based on these results, we can conclude that crown thinnings are more appropriate than low thinnings for tending of pure beech stands (Dhôte 1997; Boncina et al. 2007; von Lüpke 1986; Guericke 2002; Štefančík 2015). However, changed natural conditions (climate change) also reflected themselves in the growth of beech stands (Pretzsch et al. 2014) as compared to the last decades. This requires new approaches in the management system of not only beech stands (Štefančík 2015).

At present, even in tending (management) of beech stands we can often encounter with combined methods in terms of the concept of "Freestyle silviculture" (Boncina 2011; Diaci et al. 2011). This is based on a free application of different methods, taking into account the economy and the condition of stands.

The paper aimed at comparison of different tending variants in the beech stand using the free crown thinning (whole area, non-whole area, methods of promising and target trees) for a period of 30 years. We focused on stand structure, parameters of quantitative (number of trees, basal area, merchantable volume, increments) and qualitative production (mass and selective stem quality). Special attention was paid to the trees of selective quality (promising and target trees).

\section{Material and methods}

\subsection{Study area}

A series of permanent research plots (PRP) Štagiar served as a research object on the territory of the University Forest Enterprise under the Technical University in Zvolen ( $\mathrm{N}=\mathrm{E}=48^{\circ} 38^{\prime}$ and $\left.19^{\circ} 02^{\prime}\right)$. This locality is situated in central Slovakia and belongs to the climate district B5, slightly damp sub-area and slightly warm area. The stand was 38 years old when the experiment started, and in growing phase of pole timber ( $\mathrm{dbh}$ from
7.6 to $8.1 \mathrm{~cm})$ from natural regeneration. Beech represented the main species (94\%) and admixed tree species (oak, birch, aspen and fir) were also presented. At present, the proportion of beech represents $96 \%$. Basic PRP characteristics are shown in Table 1.

Table 1. Basic characteristics of the series of permanent research plot (PRP) Štagiar.

\begin{tabular}{lc}
\hline \multicolumn{1}{c}{ Characteristic } & PRP Štagiar \\
\hline Establishment of PRP & 1984 \\
Age of stand [years] & 38 (in 1984) \\
Site index & 26 \\
Geomorphologic unit & Kremnické vrchy \\
Exposition & West \\
Altitude [m] & 620 \\
Inclination [degree] & $15-20$ \\
Parent rock & Andesites \\
Soil unit & Cambisol \\
Average annual temperature $\left[{ }^{\circ} \mathrm{C}\right]$ & 6.6 \\
Sum of average annual precipitation [mm.year $\left.{ }^{-1}\right]$ & $900-950$ \\
\hline
\end{tabular}

Almost no interventions were performed until the time of PRP series establishment. If there were any interventions, it was only a weak local intervention solely into the suppressed level in the form of selective felling (Štefančík 1974).

The PRP series consists of four subplots (each with an area of 0.25 hectares) which are arranged side by side (along the contour line) and always separated from each other by a 15 meters wide isolation belt of trees at least. The centre of each subplot is marked with a so- called cross-cutting belt having a width of $10 \mathrm{~m}$ (an area of $0.05 \mathrm{ha}$ ). All living trees with the diameter of $3.6 \mathrm{~cm}$ and greater $\left(\mathrm{d}_{1,3}\right)$, or those trees which reached the specified diameter during the measurements, are registered with numbers on all these subplots.

Four variants of the free crown thinning are investigated on these plots (Štefančík 1984):

Subplot I - the free crown thinning on the whole area, the method of promising trees, later the method of target trees at stand age of 58 years.

Subplot II - the free crown thinning on non-whole area, tending realised inside of growth space of target trees only, the method of target trees, salvage cutting on the whole area.

Subplot III - the free crown thinning on non-whole area, the method of promising trees (the method of target trees at stand age of 58 years) realised on circular plots with diameter $4 \mathrm{~m}$ and spacing $8 \mathrm{~m}$ (distance between centre of circular plots).

Subplot IV - combined selective method, moderate low thinning and the free crown thinning by method of target trees was used by the first thinning, in next thinning only the free crown thinning on whole-area was used, method of target trees. 


\subsection{Data collection}

Standard biometric measurements of quantitative parameters (diameter $\mathrm{d}_{1.3}$, tree height and height of the crown base, the dimensions of the crown in horizontal projection) were conducted on each subplot. To estimate qualitative production, trees were classified by silvicultural (biological) and commercial (technical) classification.

The silviculture quality classification included:

a) sociological position of trees according to Štefančík (1974);

1. dominant tree

2. co-dominant tree

3. suppressed tree still vital to reach the stand crown level

4. suppressed tree but not vital to reach the stand crown level

5. dying or dead suppressed tree

b) stem quality grades;

1. straight high-quality stem without knots, with no visible external damage

2. average-quality stem, curvature allowed only in the higher one third part of the stem, low number of small knots ( 1 or 2 pieces per running meter) is allowed, with no external damage (fungi, insects, necrosis)

3. low-quality stem with high number of knots (more than 2 pieces per running meter), with twisted or stem with curvature, with external visible damage (fungi, insects, necrosis)

c) crown quality: According to the size: 1 . appropriate-sized symmetric crown; 2 . smaller-sized suppressed, but able to regenerate; 3 . overlarge-sized crown; 4. small-sized, unable to regenerate.

For suppressed trees $\left(3^{\text {rd }}-5^{\text {th }}\right.$ sociological class $)$, crown is assessed using only three quality grades: 1 good, 2 - average, and 3 - bad.

Concerning the commercial quality assessment, only the low part (low half) of the stem to the height of the crown base was assessed using the following classes: 1 high quality (A), 2-average quality (B), 3-lower quality (industrial wood) (C), and 4 - firewood (D).

Repeated measurements of parameters and evaluation of quality traits has been performed at regular fiveyearly intervals on all plots. So far, seven biometric measurements and tending interventions were implemented. Field-Map technology determined the position of living trees in a polar coordinate system $(\mathrm{x}, \mathrm{y})$.

\subsection{Data processing and analyses}

Quantitative characteristics from experiments were processed by standard biometric and statistical methods in terms of usual methodologies for the research on thin- nings (Štefančík 1974) using Excel software package, QC Expert (Kupka 2008) and growth simulator Sibyla (Fabrika 2005). Indices of diameter and height differentiation for individual PRP were calculated according to Füldner (1995). Tree volume was calculated using the volume equations published by Petráš \& Pajtík (1991). The quantitative production was calculated according to standard methods and formula (Priesol \& Polák 1991). Index of total stand (both for basal area and volume) was calculated as a share of total production (basal area or volume) at the age of 68 years (last measurement) to total stand at the age of 38 years (first measurement, before realised thinning).

At each repeated measurement and for each subplot, measured tree heights were especially equalized by a function developed by Michailoff (1943):

$$
h(d)=1,3+b_{1} \cdot e^{\left(\frac{-b_{2}}{d}\right)}
$$

wherein, $\mathrm{b}_{1}, \mathrm{~b}_{2}$ - the parameters of the regression function; $\mathrm{d}$ - diameter $\mathrm{d}_{1,3}[\mathrm{~cm}] ; \mathrm{h}$ - height [m].

Crown width, crown length, slenderness quotient, live crown ratio (crown length to tree height), crown projection area and crown surface area (hereafter crown area), crown volume and basal area were derived. Based on four crown radii, the mean crown width $(\mathrm{CW})$ was calculated:

$$
C W=\Sigma C R_{1-4} / 2
$$

wherein, CR is crown radius.

Crown length was defined as the vertical distance from the crown base to the top of the crown. Slenderness quotient represents tree height and dbh ratio. The hundred largest trees (with the largest $\mathrm{dbh}$ ) per hectare were selected to calculate slenderness quotient $(\mathrm{h} / \mathrm{dbh}$ ratio). Crown projection area (using the formula for a circle) and crown surface area (CA) was calculated as (Kramer 1988; Fichtner et al. 2013):

$$
\left.C A=\pi C R / 6 C L^{2}\left[\left(4 C L^{2}-C R^{2}\right)^{3 / 2}-C R^{3}\right)\right]
$$

wherein, $C R$ is crown radius and $C L$ is crown length.

Crown volume $(\mathrm{CV})$ was calculated as (Assmann 1968) for broadleaved tree species:

$$
C V=\pi / 8\left(C W^{2} . C L\right)
$$

wherein, CW is crown width and CL is crown length.

To determine the statistical significance of differences among selected parameters, one-factor analysis of variance ANOVA from the programming package QC Expert, Version 3.1 was used.

Data obtained from the silvicultural and commercial stand quality assessment served for the calculation of average silvicultural quality. This calculation was done separately for the stem and crown as the arithmetic mean of quality traits. Changes in the average silvicultural quality for two time periods (the first and last time period) were compared by means of the index "pom", which 
reflects the dynamic changes in the silvicultural quality (Štefančík 1974):

$$
p o m=\frac{K v}{k v} \cdot 100
$$

wherein, $\mathrm{Kv}$ - is average quality at the beginning of time periods being compared and $\mathrm{kv}$ - is the average quality at the end of time periods being compared.

If the average quality for the given period improved, then pom $>100$, or if the quality worsened, then pom $<$ 100 . Average stem and crown quality (grade) was calculated for the whole (main) stand, and also separately for the crown stand level ( $1^{\text {st }}$ and $2^{\text {nd }}$ sociological class), or suppressed stand level ( $3^{\text {rd }}$ to $5^{\text {th }}$ sociological class). Similarly, we proceeded in evaluation of the commercial quality according to the methodology by Štefančík (1974, 1976).

\section{Results}

\subsection{Stand structure}

At the beginning of the research, the structure (diameter and height) of all subplots was in fact equal. Values of the mean diameter $\left(\mathrm{d}_{\mathrm{g}}\right)$ of following subplots I, II, III and IV $(8.1 \mathrm{~cm}, 7.6 \mathrm{~cm}, 7.9 \mathrm{~cm}$ and $7.7 \mathrm{~cm})$ and also of the mean height $\left(\mathrm{h}_{\mathrm{g}}\right)-13.3 \mathrm{~m}, 12.7 \mathrm{~m}, 12.4 \mathrm{~m}$ and $12.4 \mathrm{~m}$ confirmed it. The differences among them were minimal and statistically insignificant (for $\alpha=0.05$ ). However, after 30 years of tending, statistically significant differences $(p<0.05)$ were found only between the subplot IV $\left(\mathrm{d}_{\mathrm{g}}=18.8 \mathrm{~cm}, \mathrm{~h}_{\mathrm{g}}=22.8 \mathrm{~m}\right)$, and other three plots I, II, and III, at the mean diameter $(16.1 \mathrm{~cm}, 15.3 \mathrm{~cm}$ and $16.2 \mathrm{~cm})$ and mean height (19.8 m, $19.2 \mathrm{~m}$ and $20.6 \mathrm{~m})$.
Slight differences in stand structure for a period of 30 years were also confirmed by the indices of diameter diversity $\left(\mathrm{TM}_{\mathrm{d}}\right)$, whose values were very similar (from 0.437 to 0.551 ). The lowest value was determined for the subplot IV, where stand's suppressed level was removed at the beginning of the investigation. This was evident even after 30 years. And, it was also proved by the values of height differentiation index $\left(\mathrm{TM}_{\mathrm{h}}\right)$. These values were lowest on the subplot IV (0.297), i.e. the small height differentiation. Other three subplots (I, II, III) reached values ranged from 0.371 to 0.466 , i.e. medium differentiation. Height structure have been documented on the Fig. 1, where the percentage of relative height position was at the beginning and end of the investigated period. At the beginning of the research, the proportion of the crown stand level ( $1^{\text {st }}$ and $2^{\text {nd }}$ sociological class) ranged between 30 and $38 \%$. During 30 years, it has changed mostly on the subplot IV when it increased to $47 \%$ while on other three subplots it was around $30 \%$.

\subsection{Quantitative production}

Development of stand characteristics during the investigated period was presented in Table 2. At subplots establishment, the initial number of trees $(\mathrm{N})$ on all subplots (except for the subplot III) was higher than 5000 tree ha $^{-1}$. Basal area (G) ranged from 24 to $27 \mathrm{~m}^{2} \mathrm{ha}^{-1}$ and the merchantable volume $\left(\mathrm{V}_{7 \mathrm{~b}}\right)$ ranged from 102 to $141 \mathrm{~m}^{3} \mathrm{ha}^{-1}$.

After 30 years, the lowest number of trees remained on the subplot IV ( $25 \%$ out of the initial number of individuals); then it remained $33 \%$ on the subplot I; $35 \%$ on the subplot II and $38 \%$ on the subplot III. The highest values of basal area were found on the subplot III and/or the subplots IV, as for the merchantable volume. On the

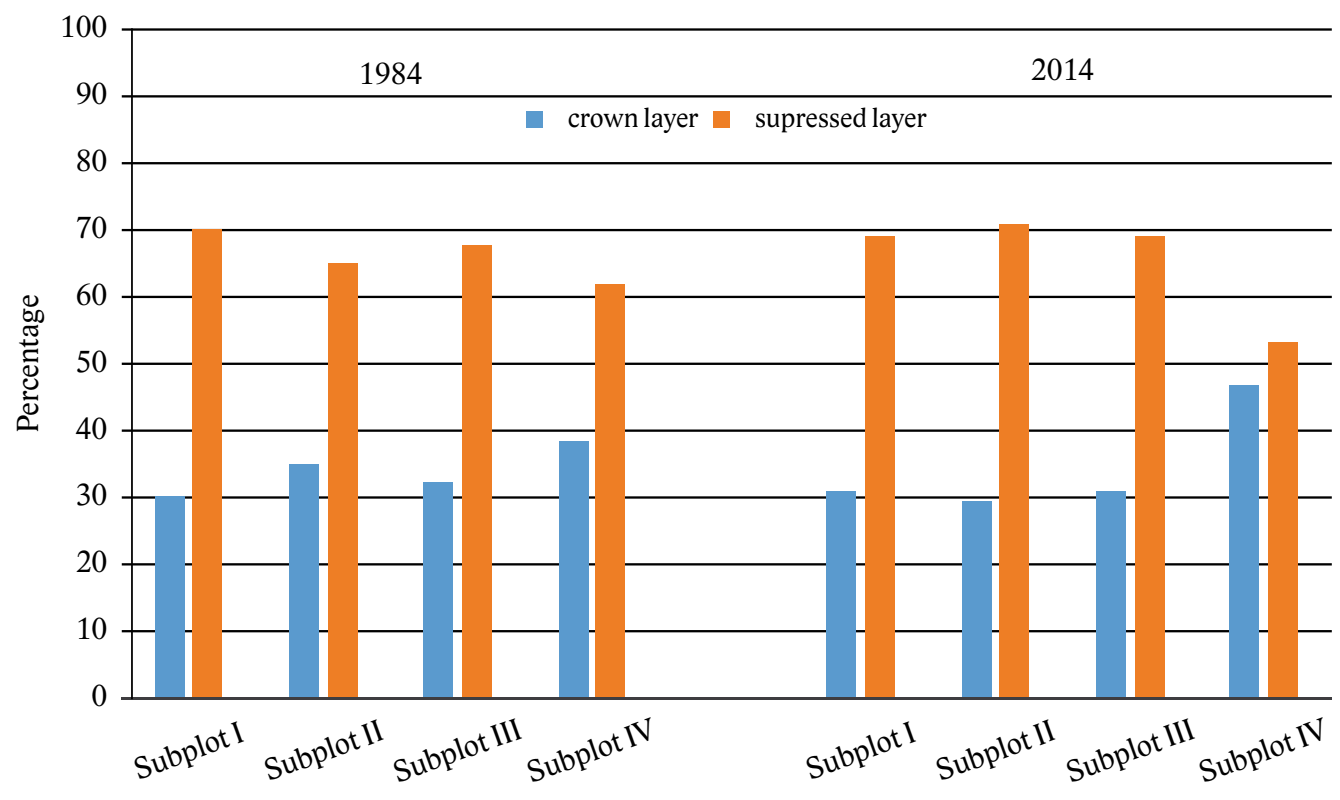

Fig. 1. Relative frequency according to growth classes. 
contrary, the lowest values were found on the subplot II, although there was the highest number of trees. Better overview of the overall quantitative production provides Table 3.

When analysed the total decrease of trees (thinnings, autoreduction, abiotic factors) for 30 years by the $\mathrm{G}$ and $\mathrm{V}_{7 \mathrm{~b}}$ parameters, we found the highest decrease on the subplot I where the whole area tending and the method of promising trees were applied. Therefore, in comparison with non-whole area tending (subplots II and III), or combined tending (subplot IV), it was necessary to remove more trees in the context of positive crown level intervention. On the contrary, the smallest decrease was recorded on the subplot III, where non-whole area intervention was performed only on circle plots around promising trees (with a diameter of 4 meters). These differences were not large because of the stand age of 68 years.
Concerning the total production (by $\mathrm{G}$ and $\mathrm{V}_{7 \mathrm{~b}}$ ), the highest values were recorded on subplots with the highest total decrease, i.e. subplots I and IV. This indicates that intensive tending had a positive effect on the total quantitative production. It was also confirmed by the index values of total production growth for the investigated period. The highest index was found on the plot IV. The same statement also applied to the values of the current annual basal area increment $\left(\mathrm{i}_{\mathrm{G}}\right)$ and volume increment $\left(\mathrm{i}_{\mathrm{V} 7 \mathrm{~b}}\right)$ in each 5-year periods (Fig. 2).

Total current volume increment for the investigated period was highest on the subplot IV $\left(15.4 \mathrm{~m}^{3} \mathrm{ha}^{-1} \mathrm{year}^{-1}\right)$ and lowest on the subplot II $\left(12.8 \mathrm{~m}^{3} \mathrm{ha}^{-1} \mathrm{year}^{-1}\right)$. The total mean volume increment reached following values: subplot IV $\left(8.1 \mathrm{~m}^{3} \mathrm{ha}^{-1}\right.$ year $\left.^{-1}\right)$, subplot I $\left(7.8 \mathrm{~m}^{3} \mathrm{ha}^{-1}\right.$ year $\left.{ }^{-1}\right)$, subplot III $\left(7.6 \mathrm{~m}^{3} \mathrm{ha}^{-1}\right.$ year $\left.^{-1}\right)$ and subplot II $\left(7.1 \mathrm{~m}^{3} \mathrm{ha}^{-1}\right.$ year $\left.^{-1}\right)$.

Table 2. Development of measured parameters on subplots.

\begin{tabular}{|c|c|c|c|c|c|c|c|c|c|}
\hline \multirow{3}{*}{ Subplot } & \multirow{3}{*}{$\begin{array}{c}\text { Stand } \\
\text { parameter }\end{array}$} & \multirow{3}{*}{$\begin{array}{c}\text { Age } \\
\text { [years] }\end{array}$} & \multirow{3}{*}{$\begin{array}{c}\text { Total stand } \\
\text { abs ha }^{-1}\end{array}$} & \multicolumn{3}{|c|}{ Decrease (Secondary stand) } & \multirow{2}{*}{\multicolumn{2}{|c|}{ Thinning intensity }} & \multirow{3}{*}{$\begin{array}{c}\text { Main stanc } \\
\text { abs ha }^{-1}\end{array}$} \\
\hline & & & & \multirow{2}{*}{$\begin{array}{c}\text { thinning living } \\
\text { trees }\end{array}$} & \multirow{2}{*}{$\begin{array}{c}\text { dead trees } \\
\%\end{array}$} & \multirow{2}{*}{ other decrease } & & & \\
\hline & & & & & & & $\mathrm{absha}^{-1}$ & \% together & \\
\hline \multirow{9}{*}{ I } & \multirow{3}{*}{$\begin{array}{l}\mathrm{N} \\
\text { tree ha }^{-1}\end{array}$} & 38 & 5,348 & 15.2 & - & - & 812 & 15.2 & 4,536 \\
\hline & & 53 & 2,668 & 3.6 & 4.5 & 1.0 & 244 & 9.1 & 2,424 \\
\hline & & 68 & 1,972 & 2.2 & 6.1 & 1.0 & 184 & 9.3 & 1,788 \\
\hline & \multirow{3}{*}{$\begin{array}{l}\mathrm{G} \\
\mathrm{m}^{2} \mathrm{ha}^{-1}\end{array}$} & 38 & 27.3 & 15.8 & - & - & 4.3 & 15.8 & 23.0 \\
\hline & & 53 & 31.0 & 6.1 & 1.5 & 0.2 & 2.4 & 7.8 & 28.6 \\
\hline & & 68 & 38.6 & 4.0 & 0.7 & 1.6 & 2.3 & 6.3 & 36.3 \\
\hline & \multirow{3}{*}{$\begin{array}{l}\mathrm{V}_{7 \mathrm{~b}} \\
\mathrm{~m}^{3} \mathrm{ha}^{-1}\end{array}$} & 38 & 141 & 16.4 & - & - & 23 & 16.4 & 118 \\
\hline & & 53 & 255 & 6.5 & 1.1 & 0.1 & 20 & 7.7 & 235 \\
\hline & & 68 & 396 & 4.3 & 0.1 & 1.1 & 22 & 5.5 & 374 \\
\hline \multirow{9}{*}{ II } & \multirow{3}{*}{$\begin{array}{l}\mathrm{N} \\
\text { tree ha }^{-1}\end{array}$} & 38 & 5,576 & 7.8 & - & - & 436 & 7.8 & 5,140 \\
\hline & & 53 & 3,124 & 6.0 & 11.4 & 0.5 & 560 & 17.9 & 2,564 \\
\hline & & 68 & 2,152 & 1.3 & 7.2 & - & 184 & 8.5 & 1,968 \\
\hline & \multirow{3}{*}{$\begin{array}{l}\mathrm{G} \\
\mathrm{m}^{2} \mathrm{ha}^{-1}\end{array}$} & 38 & 25.4 & 11.5 & - & - & 2.9 & 11.5 & 22.5 \\
\hline & & 53 & 29.6 & 8.3 & 2.3 & 0.3 & 3.2 & 10.9 & 26.4 \\
\hline & & 68 & 36.9 & 1.5 & 1.1 & - & 0.9 & 2.6 & 36.0 \\
\hline & \multirow{3}{*}{$\begin{array}{l}\mathrm{V}_{7 \mathrm{~b}} \\
\mathrm{~m}^{3} \mathrm{ha}^{-1}\end{array}$} & 38 & 112 & 14.4 & - & - & 16 & 14.4 & 96 \\
\hline & & 53 & 226 & 8.7 & 0.3 & 0.3 & 21 & 9.3 & 205 \\
\hline & & 68 & 357 & 1.4 & 0.2 & - & 6 & 1.6 & 351 \\
\hline \multirow{9}{*}{ III } & \multirow{3}{*}{$\begin{array}{l}\mathrm{N} \\
\text { tree ha }\end{array}$} & 38 & 4,832 & 5.5 & - & - & 264 & 5.5 & 4,568 \\
\hline & & 53 & 3,052 & 5.5 & 7.2 & 0.8 & 412 & 13.5 & 2,640 \\
\hline & & 68 & 2,112 & 0.4 & 13.0 & 0.4 & 292 & 13.8 & 1,820 \\
\hline & \multirow{3}{*}{$\begin{array}{l}\mathrm{G} \\
\mathrm{m}^{2} \mathrm{ha}^{-1}\end{array}$} & 38 & 23.9 & 7.5 & - & - & 1.8 & 7.5 & 22.1 \\
\hline & & 53 & 33.6 & 9.9 & 1.2 & 0.2 & 3.8 & 11.3 & 29.8 \\
\hline & & 68 & 39.1 & 1.5 & 1.8 & 0.2 & 1.4 & 3.5 & 37.7 \\
\hline & \multirow{3}{*}{$\begin{array}{l}\mathrm{V}_{7 \mathrm{~b}} \\
\mathrm{~m}^{3} \mathrm{ha}^{-1}\end{array}$} & 38 & 114 & 8.6 & - & - & 10 & 8.6 & 104 \\
\hline & & 53 & 274 & 11.0 & 0.1 & 0 & 30 & 11.1 & 244 \\
\hline & & 68 & 408 & 1.8 & 0.4 & 0.1 & 9 & 2.3 & 399 \\
\hline \multirow{9}{*}{ IV } & \multirow{3}{*}{$\begin{array}{l}\mathrm{N} \\
\text { tree ha }^{-1}\end{array}$} & 38 & 5,175 & 51.5 & - & - & $150+2,517$ & $2.9+48.6$ & 2,508 \\
\hline & & 53 & 1,804 & 9.3 & 0.7 & 0.2 & 183 & 10.2 & 1,621 \\
\hline & & 68 & 1,401 & 3.9 & 3.0 & - & 97 & 6.9 & $\begin{array}{l}1,021 \\
1,304\end{array}$ \\
\hline & \multirow{3}{*}{$\begin{array}{l}\mathrm{G} \\
\mathrm{m}^{2} \mathrm{ha}^{-1}\end{array}$} & 38 & 24.3 & 24.0 & - & - & $1.3+4.5$ & $5.2+18.9$ & 18.5 \\
\hline & & 53 & 30.0 & 10.9 & 0.2 & 0.1 & 3.4 & 11.2 & 26.6 \\
\hline & & 68 & 38.0 & 4.6 & 0.7 & - & 2.0 & 5.3 & 36.0 \\
\hline & & 38 & 102 & 11.6 & - & - & $6.8+5.1$ & $6.6+4.9$ & 90 \\
\hline & $v_{7 b}$ & 53 & 264 & 11.4 & 0.1 & 0 & 31 & 11.5 & 233 \\
\hline & $\mathrm{m}^{3} \mathrm{ha}^{-1}$ & 68 & 424 & 4.8 & 0.2 & - & 21 & 5.0 & 403 \\
\hline
\end{tabular}

Comment: On the subplot IV the first data relates to thinning intensity of the free crown thinning and the second one (after + ) of the low thinning.

Table 3. Development of quantitative production of the stand for 30 years.

\begin{tabular}{|c|c|c|c|c|c|c|}
\hline \multirow{3}{*}{ Subplot } & \multirow{3}{*}{$\begin{array}{c}\text { Age } \\
\text { [years] }\end{array}$} & \multicolumn{5}{|c|}{ Total production } \\
\hline & & \multirow{2}{*}{$\begin{array}{c}\mathrm{N} \\
{\left[\text { tree ha }^{-1}\right]}\end{array}$} & \multicolumn{2}{|r|}{ Totar pivauction } & \multicolumn{2}{|c|}{$\mathrm{V}_{7 \mathrm{~h}}$} \\
\hline & & & {$\left[\mathrm{m}^{2} \mathrm{ha}^{-1}\right]$} & index of total stand & {$\left[\mathrm{m}^{3} \mathrm{ha}^{-1}\right]$} & index of total stand \\
\hline I & $38-68$ & 5,348 & 58.9 & 2.160 & 530 & 3.764 \\
\hline II & $38-68$ & 5,576 & 56.7 & 2.231 & 480 & 4.282 \\
\hline III & $38-68$ & 4,832 & 55.3 & 2.316 & 520 & 4.577 \\
\hline IV & $38-68$ & 5,175 & 58.2 & 2.392 & 551 & 5.430 \\
\hline
\end{tabular}

Explanatory notes: $\mathrm{N}$ - Number of trees, $\mathrm{G}$ - Basal area, $\mathrm{V}_{7 \mathrm{~b}}$ - Merchantable volume. 


\subsection{Analysis of silvicultural interventions}

First three interventions (till the stand age about 50 years) and/or first four interventions in the case of the subplot IV, were strongest on all the subplots (except for the subplot III). Intensity of intervention (out of the basal area) ranged from 11 to $24 \%$. On the contrary, intensity on the subplot III did not exceed $10 \%$ during the entire 30 years of tending, which is a logical consequence of the fact that there were only interventions on small growth subplots and not on the whole area. This area, however, had the highest decrease by autoregulation (self-thinning), which represented $8 \%$ out of the basal area total production. The highest decrease due to thinning was found on the subplot IV ( $37 \%$ out of the basal area total production).

A certain proportion of thinning was caused by a sanitation selection due to beech bark necrosis disease. However, the positive crown level selection was always prevailing on all subplots. The first thinning on the subplot IV was the only exception, where the suppressed trees were removed up to the $78 \%$ out of the basal area and/or $43 \%$ out of the merchantable volume.

\subsection{Qualitative production}

\subsubsection{Selective quality of the stand}

Development of the trees of selective quality (promising and target) is shown in Table 4.

Table 4. Development of the trees of selective quality on PRP Štagiar.

\begin{tabular}{|c|c|c|c|c|c|c|}
\hline \multirow[b]{2}{*}{ Subplot } & \multirow[b]{2}{*}{$\begin{array}{c}\text { Age } \\
\text { [years] }\end{array}$} & \multirow[b]{2}{*}{$\begin{array}{c}\text { Number of trees } \\
\left.\text { [tree ha }{ }^{-1}\right]\end{array}$} & \multicolumn{2}{|c|}{ Basal area } & \multicolumn{2}{|c|}{ Merchantable volume } \\
\hline & & & {$\left[\mathrm{m}^{2} \mathrm{ha}^{-1}\right]$} & $\begin{array}{c}\text { \% out } \\
\text { of main } \\
\text { stand }\end{array}$ & {$\left[\mathrm{m}^{3} \mathrm{ha}^{-1}\right]$} & $\begin{array}{l}\% \text { out } \\
\text { of main } \\
\text { stand }\end{array}$ \\
\hline \multirow{3}{*}{ I } & 38 & 316 & 5.2 & 22.7 & 38 & 32.5 \\
\hline & 53 & 284 & 10.8 & 37.7 & 107 & 45.3 \\
\hline & 68 & 160 & 10.5 & 28.8 & 124 & 33.0 \\
\hline \multirow{3}{*}{ II } & 38 & 180 & 2.2 & 9.8 & 14 & 14.9 \\
\hline & 53 & 180 & 6.0 & 22.7 & 58 & 28.6 \\
\hline & 68 & 176 & 10.4 & 28.9 & 119 & 33.8 \\
\hline \multirow{3}{*}{ III } & 38 & 208 & 2.9 & 13.3 & 20 & 19.7 \\
\hline & 53 & 176 & 6.5 & 21.9 & 65 & 26.8 \\
\hline & 68 & 156 & 9.6 & 25.5 & 117 & 29.4 \\
\hline \multirow{3}{*}{ IV } & 38 & 209 & 2.7 & 14.5 & 18 & 19.9 \\
\hline & 53 & 208 & 7.2 & 27.0 & 72 & 30.8 \\
\hline & 68 & 200 & 12.5 & 34.7 & 156 & 38.7 \\
\hline
\end{tabular}
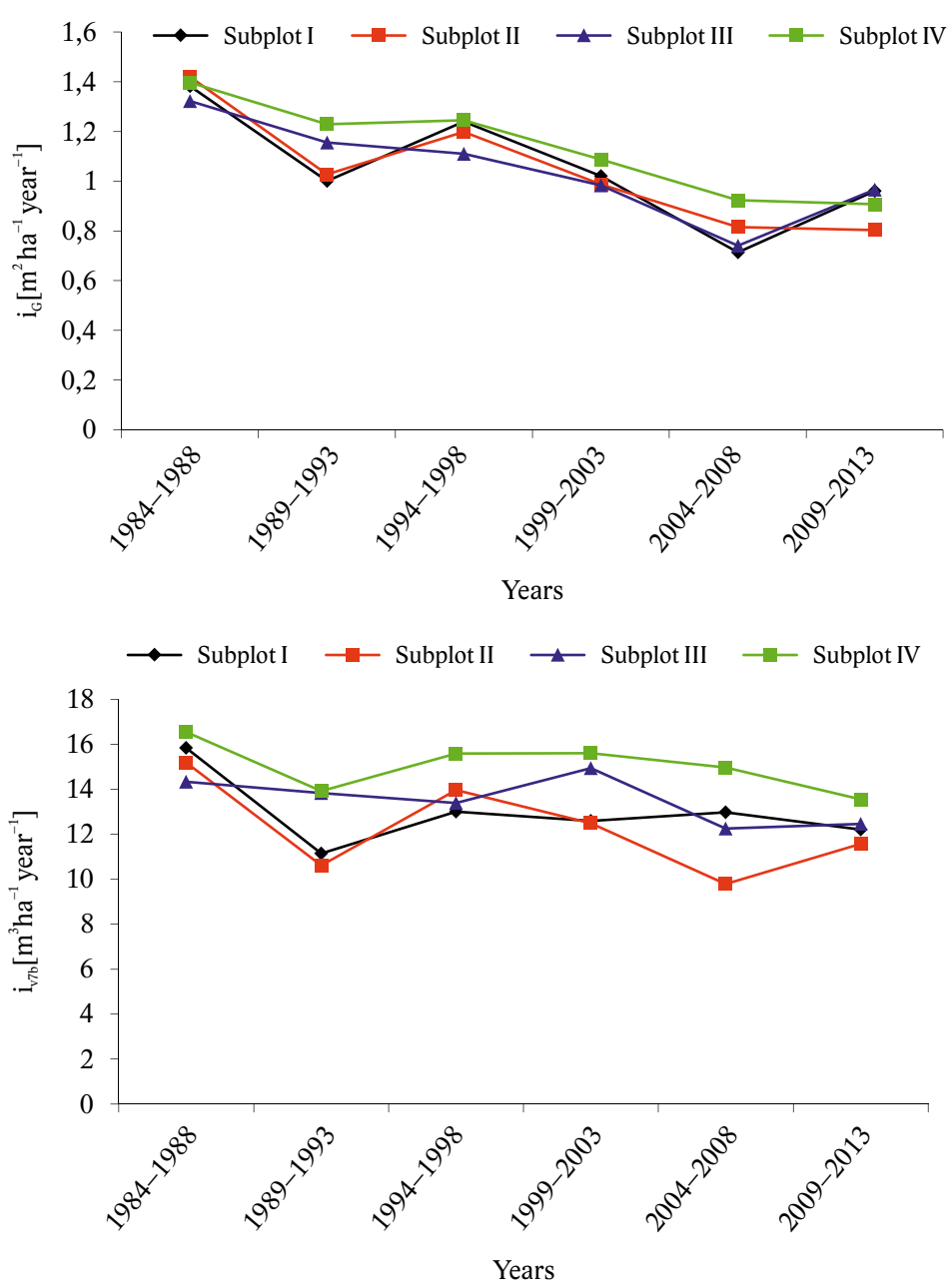

Fig. 2. Current annual basal area increment $\left(\mathrm{i}_{\mathrm{G}}\right)$ and current annual merchantable volume increment $\left(\mathrm{i}_{\mathrm{V} 7 \mathrm{~b}}\right)$. 
Promising trees (subplot I and III) and target trees (subplot II and IV) were selected at the beginning of the research at the age of 38 years. Subplots with an initial method of promising trees transformed into subplots with a method of target trees (TT) from the stand age of 58 years. It explained marked decrease in the number of trees of selective quality on those subplots aged 68 years.

After 30 years, the TT method has been already applied on all subplots, and it shows that the highest number of TT at age of 68 years was on the subplot IV. At the same time, the quantitative parameters (basal area, merchantable volume) were the highest on this subplot. This was also confirmed by their percentage of the main stand and their values of crown parameters.

Table 5 shows the selected parameters of target trees crowns after 30 years of tending. Values obtained were more or less balanced, and/or some values (crown surface area, crown projection area, crown volume) were highest on the subplot IV, although the differences were not significant among subplots (for $\alpha=0.05$ ).

\subsubsection{Mass quality of the stands}

\subsubsection{Silvicultural quality of the stand}

Silvicultural quality of the main stand, the crown stand level ( $1^{\text {st }}$ and $2^{\text {nd }}$ sociological class) and suppressed stand level ( $3^{\text {rd }}$ to $5^{\text {th }}$ sociological class $)$ was presented in Table 6 .

At the beginning of the research, the stem and crown quality of crown level trees was better than the quality of suppressed ones. Regarding the stem, average values of the stand ranged from 2.38 to 2.70 and/or from 1.84 to 2.64 for the crown. Here, the effect of the first combined thinning became evident for the subplot IV, where suppressed trees were removed, which generally has the worst crown quality in uncultivated stands.

After tending (30 years) interventions, the stem quality of the main stand deteriorated on all subplots. At the same time, we found decrease of the crown quality on all the subplots (except for the subplot I). It was surprising mainly for the subplot IV.

Table 5. Characteristics of target (crop) trees at the age of 68 years after 30 years of investigation.

\begin{tabular}{lcccc}
\hline \multicolumn{1}{c}{ Characteristic } & \multicolumn{4}{c}{ Statistics [mean (coefficient of variation)] } \\
\hline & Subplot I & Subplot II & Subplot III & Subplot IV \\
DBH [cm] & $28.3^{\mathrm{a}}(14.5)$ & $27.4^{\mathrm{a}}(12.8)$ & $27.0^{\mathrm{a}}(15.1)$ & $27.0^{\mathrm{a}}(14.9)$ \\
Height [m] & $24.3^{\mathrm{a}}(5.4)$ & $24.0^{\mathrm{a}}(5.2)$ & $24.9^{\mathrm{ab}}(5.4)$ & $25.6^{\mathrm{bc}}(3.7)$ \\
Stem slenderness & $0.81^{\mathrm{a}}(7.9)$ & $0.83^{\mathrm{ab}}(7.7)$ & $0.87^{\mathrm{bc}}(6.5)$ & $0.87^{\mathrm{bc}}(6.9)$ \\
Crown width [m] & $5.7^{\mathrm{a}}(14.4)$ & $5.6^{\mathrm{a}}(16.0)$ & $5.3^{\mathrm{a}}(13.9)$ & $5.7^{\mathrm{a}}(16.5)$ \\
Crown length [m] & $11.6^{\mathrm{a}}(12.4)$ & $11.6^{\mathrm{a}}(12.4)$ & $12.0^{\mathrm{a}}(15.3)$ & $12.1^{\mathrm{a}}(11.6)$ \\
Crown ratio & $0.48^{\mathrm{a}}(9.2)$ & $0.48^{\mathrm{a}}(10.2)$ & $0.48^{\mathrm{a}}(12.2)$ & $0.47^{\mathrm{a}}(10.2)$ \\
Crown surface area $\left[\mathrm{m}^{2}\right]$ & $138.6^{\mathrm{a}}(24.0)$ & $135.7^{\mathrm{a}}(25.7)$ & $132.7^{\mathrm{a}}(21.6)$ & $143.2^{\mathrm{a}}(22.3)$ \\
Crown projection area $\left[\mathrm{m}^{2}\right]$ & $26.3^{\mathrm{a}}(28.4)$ & $25.5^{\mathrm{a}}(33.3)$ & $22.7^{\mathrm{a}}(26.8)$ & $26.3^{\mathrm{a}}(33.8)$ \\
Crown volume $\left[\mathrm{m}^{3}\right]$ & $155.5^{\mathrm{a}}(36.7)$ & $150.5^{\mathrm{a}}(43.8)$ & $137.3^{\mathrm{a}}(31.9)$ & $160.6^{\mathrm{a}}(38.1)$ \\
\hline
\end{tabular}

Comment: Note: The values with the different letters are significantly different on the level $\alpha=0.05$.

Table 6. Silvicultural (biological) quality of the stand for the period of 30 years.

\begin{tabular}{|c|c|c|c|c|c|}
\hline Subplot & Age [years] & Silvicultural quality & Crown level & Suppressed level & Total stand \\
\hline \multirow{8}{*}{ I } & \multirow{4}{*}{38} & stem & 2.307 & 2.808 & 2.656 \\
\hline & & pom & 100 & 100 & 100 \\
\hline & & crown & 2.062 & 2.889 & 2.639 \\
\hline & & pom & 100 & 100 & 100 \\
\hline & \multirow{4}{*}{68} & stem & 2.478 & 2.955 & 2.808 \\
\hline & & pom & 93.1 & 95.0 & 94.6 \\
\hline & & crown & 1.754 & 2.981 & 2.602 \\
\hline & & pom & 117.6 & 96.9 & 101.4 \\
\hline \multirow{8}{*}{ II } & \multirow{4}{*}{38} & stem & 2.410 & 2.857 & 2.700 \\
\hline & & pom & 100 & 100 & 100 \\
\hline & & crown & 2.010 & 2.914 & 2.596 \\
\hline & & pom & 100 & 100 & 100 \\
\hline & \multirow{4}{*}{68} & stem & 2.563 & 2.977 & 2.856 \\
\hline & & pom & 94.0 & 96.0 & 94.5 \\
\hline & & crown & 1.771 & 3.003 & 2.642 \\
\hline & & pom & 113.5 & 97.0 & 98.3 \\
\hline \multirow{8}{*}{ III } & \multirow{4}{*}{38} & stem & 2.274 & 2.891 & 2.692 \\
\hline & & pom & 100 & 100 & 100 \\
\hline & & crown & 1.890 & 2.851 & 2.540 \\
\hline & & pom & 100 & 100 & 100 \\
\hline & \multirow{4}{*}{68} & stem & 2.593 & 2.962 & 2.848 \\
\hline & & pom & 87.7 & 97.6 & 94.5 \\
\hline & & crown & 1.800 & 3.006 & 2.635 \\
\hline & & pom & 105.0 & 94.8 & 96.4 \\
\hline \multirow{8}{*}{ IV } & \multirow{4}{*}{38} & stem & 2.279 & 2.673 & 2.379 \\
\hline & & pom & 100 & 100 & 100 \\
\hline & & crown & 1.697 & 2.247 & 1.837 \\
\hline & & pom & 100 & 100 & 100 \\
\hline & \multirow{4}{*}{68} & stem & 2.507 & 2.886 & 2.709 \\
\hline & & pom & 90.9 & 92.6 & 87.8 \\
\hline & & crown & 1.781 & 2.976 & 2.417 \\
\hline & & pom & 95.2 & 75.5 & 76.0 \\
\hline
\end{tabular}


The main stand contained the highest proportion of stems with the best quality $\left(1^{\text {st }}\right.$ and $2^{\text {nd }}$ grade $)$ on the subplot IV (27\%) and the lowest proportion on the subplot II (14\%). Investigation of the long-term changes merely in the stand level ( $1^{\text {st }}$ and $2^{\text {nd }}$ sociological class) showed decrease of the stem quality on all the subplots and thus in the entire stand, as well.

By comparison with other subplots, the proportion of trees with the best crown quality ( $1^{\text {st }}$ grade) was best again on the subplot IV (18\%), while on the remaining subplots it was equal (11\%).

\subsubsection{Commercial quality of the stand}

In terms of the qualitative production and/or subsequent assortment classification, the lower half of the thickest stems was crucial. In the crown level $\left(1^{\text {st }}\right.$ and $2^{\text {nd }}$ sociological class), a comparison of the commercial quality of the lower half of stem after 30 years of tending (Fig. 3) pointed to quality improvement (especially in a the first quality grade) in opposite to the beginning of research on all the subplots.
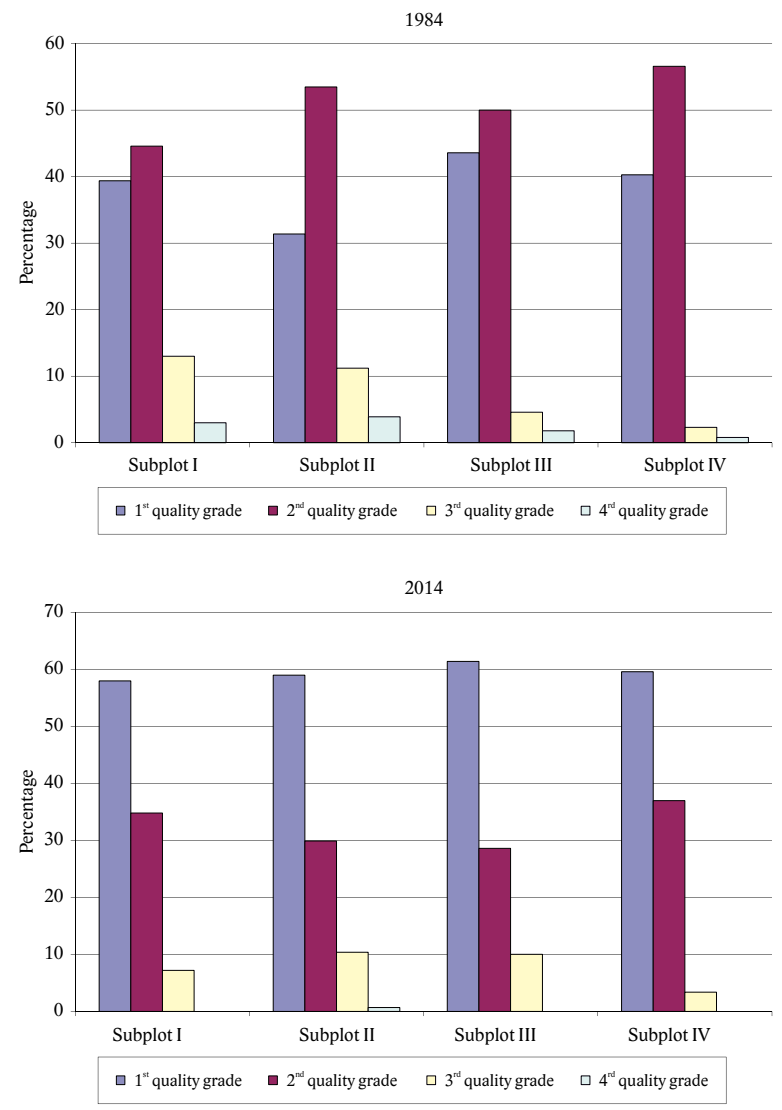

Fig. 3. Lower half of stem according to number of trees, crown level trees only in 1984 and 2014.

In this analysis, we have also investigated the basal area percentage of only the lower half of stem from crown level trees and for each quality grade (Fig. 4). The highest percentage of the first quality grade was on the subplot
IV (68\%), but the percentage was only slightly lower (61 $-65 \%)$ on the remaining subplots. When ascertained the crown quality of the crown level trees (from the number of trees), it was found that values were virtually identical (about 60\%). This corresponded to the fact that the same type of thinning was being applied on all the subplots.

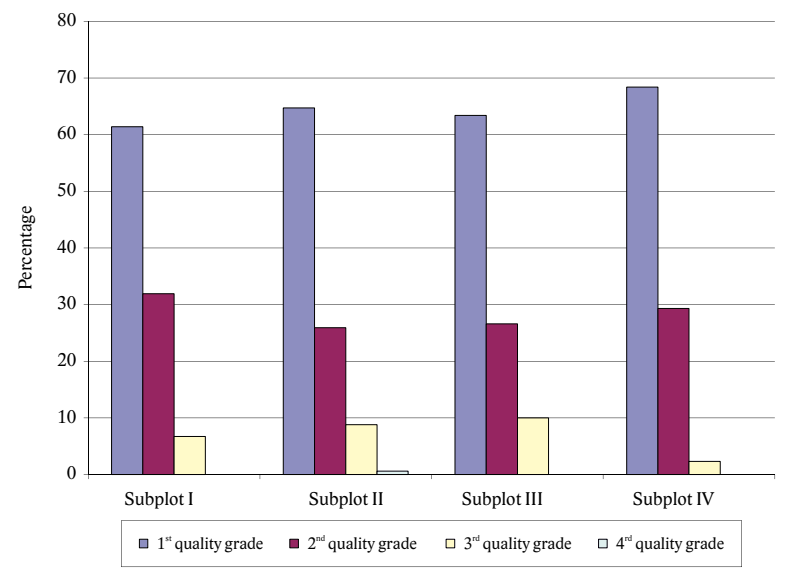

Fig. 4. Lower half of stem according to basal area, crown level trees only in 2014.

\section{Discussion}

Proper timing is crucial for the effectiveness of not only beech stands tending. Our experiment was established in the stand without prior tending at age of 38 years. The stand age can be considered adequate at the beginning of experiment, although there are known field trials where tending of beech stands began in the young growth stage (Réh 1968, 1969; Jurča, Chroust 1973; Tufekcioglu et al. 2005). Establishing of experiments is considered optimal not later than in the small pole stage (Šebík 1971; Štefančík 1974; von Lüpke 1986; Utschig $\&$ Küsters 2003). However, there are known experiments with the beginning of tending at the stage of pole timber (Štefančík 1974; Klädtke 1997). The question is whether this will be reflected on the quantity and value production of stands. Present knowledge on delayed tending in beech stands (Réh 2004; Štefančík 2013) point out that the desired dimensions (parameters) in terms of quantity of production can be more or less also achieved by delayed tending. However, it depends on the site and tending method and/or a type of thinning (Štefančík 2013a). It is also similar in case of qualitative production, where it is required to start with tending with moderate interventions early. This is confirmed by Korpel's results (1988), who found out significantly higher number of individuals of the highest quality aged about 40 years at systematic and intensive tending from the stage of young growth in comparison with the stand with delayed (neglected) tending. This is evidenced by the conclusions of Mlinšek \& Bakker (1990), who analysed 50 target beech trees aged from 140 to 150 years on two sites in Slovenia. The 
results showed that the trees with even and moderate radial growth produced most knot-free wood. Trees that first had narrow annual rings at a young age and then suddenly produced wide annual rings had excellent shape of the stem, but produced less knot-free wood compared to trees with moderate radial growth.

Our experiment does not include a control subplot (without interventions), which is generally a rule at comparative experiments. At present, however, there are results of numerous and long-term experiments (Utschig \& Küsters 2003; Pretzsch 2005), which clearly demonstrated the justifiability and advantages of crown level thinning against to plots without intervention. The results of many authors (Hein et al. 2007; Boncina et al. 2007; Štefančík 2015) confirmed that crown level thinning with positive selection are the most appropriate methods especially for growing of selective quality stands. The method of candidates (Schädelin 1934; Leibundgut 1966; Réh 2004), promising trees (Štefančík 1984) or target trees (Boncina et al. 2007; Diaconu et al. 2015; Štefančík 2015) is preferred. Advantages of the target trees method were also confirmed by Hein et al. (2007), who based on a 35-year research found a higher stem quality and/or net value production on plots with thinnings and selected target trees in comparison with plots where interventions according to Assmann's optimal basal area were performed. Apart from the mentioned methods of tending in beech stands, in Germany were developed another thinning interventions in the past. These methods were focused on "light increment utilisation" of beech stand. Freist (1962) recommended more intense crown thinning at stand age of 40 to 50 years, with the aim to cultivate of 100 target trees at the end of rotation (140 years) with its target dbh of $60 \mathrm{~cm}$ or more. Similarly, the model of "stand opening" (Lichtwuchsmodell) according to Altherr (1971) assumed basal area of $20 \mathrm{~m}^{2} \mathrm{ha}^{-1}$ at stand age 70 years, with target dbh of 35 to $40 \mathrm{~cm}$. The method of "group selection thinning" according to Kató \& Mülder (1983) should be considered as one of variant performed by our experiment (non-whole tending). The crucial difference between target tree cultivation applied in our subplots and the mention two methods is evident. Namely, Altherr's model and "Gruppendurchforstung” (Kató \& Mulder 1983) allows an irregular arrangement of target trees in stand.

In our experiment, the target trees were selected at the age of 38 years and/or 58 years. This is in compliance with the recommendations by Štefančík (1975), who states that the target trees need to be selected at the age of 60 years or no later than in the middle of rotation age. Bončina et al. (2007) selected target trees at the age of 70 years and their number depended on the intensity of thinning to be carried out in the coming years. Different opinions are available, related to a desired number of crop trees in beech stands. For example, Abetz (1979) and Altherr (1981) recommended 110 trees ha $^{-1}$. A higher number of these trees was pointed out by Spellmann $\&$
Nagel (1996) and Guericke (2002) representing 250 and $100-300$ selected and marked crop trees, respectively. Later on, due to the development of the crown surface area a decreasing number of crop trees from 200 to 80 stems ha ${ }^{-1}$ with advancing age was registered. In Switzerland, Kurt (1982) presented 80 - 120 target trees for beech with desired parameters in relation to DBH as given by yield tables. Based on the study in 20 stands in Switzerland, Leibundgut (1982) recommended 210 crop trees for beech at a top height of $35 \mathrm{~m}$. A lower number of crop trees is typical and common in France, ranging from 80 to 100 trees ha $^{-1}$ (Bouchon et al. 1989). A similar opinion was published by Klädtke (2002), who pointed out that the selection of more than 100 crop trees is not recommended, because the probability of red heart formation increases strongly due to a much longer production time. In Slovakia, a model of the future mature beech stand (stand age 110 - 130 years) was developed by Štefančík (1984). This model presents 5 variants depending on the site conditions (acid and fertile). The number of target trees ranged from 121 to 217 stems ha $^{-1}$, within the mean spacing between target trees of $7.6 \mathrm{~m}$. Ascertained numbers of target trees in our experiment are consistent with the mentioned model.

Tending intensity also plays an important role. Based on the assessment of the results of 130 years old experiment on a PRP Elmstein 20 (Germany) Utschig \& Küsters (2003) stated that the final economic evaluation showed production of more valuable assortments when applying more intense thinnings. This more or less compensated higher production of wood obtained by applying moderate interventions. Similarly, based on research in beech and spruce stands, Spellmann \& Nagel (1996) recommended early and intense crown level thinnings. In our experiment, the most intensive interventions were performed on the subplot I (38.3\% out of the total basal area production) and subplot IV (38.1\%), i.e. where the most favourable values of target tree were found. This is consistent with the knowledge that more intense interventions support an increase in diameter increment of target trees (Klädtke 1997; Boncina et al. 2007). This was confirmed by our experiment as well, when the maximum diameter increment of target trees was recorded on the subplot IV where the most intensive tending was applied. Total volume increment on the subplot IV was $8.1 \mathrm{~m}^{3}$ $\mathrm{ha}^{-1}$ year $^{-1}$ and/or or $7.8 \mathrm{~m}^{3} \mathrm{ha}^{-1}$ year $^{-1}$ on the subplot I. Klädtke (1997) states lower value of $6.0 \mathrm{~m}^{3} \mathrm{ha}^{-1} \mathrm{year}^{-1}$.

Comparable results were also obtained from the assessment of the stem quality. Concerning the stand level, Badoux (1939) discovered 28 - 35\% of stems with the highest quality on the plot with crown thinning. This proportion is lower in comparison with our results from investigated PRP where it reached about $60 \%$ of the number of trees and 65 to $70 \%$ out of the basal area. However, in assessing the mass stem and crown quality (the stand as a whole) no improvement was recorded in 30 years. It was unexpected on subplot IV, where all 
suppressed trees were removed at the beginning. We explained it by the fact that the number of suppressed trees increased on this subplot from the beginning of this investigation (as a consequence of height movements for 30 years). This participated in the deterioration of the average quality of the main stand. This is due to the fact that suppressed trees, which are numerous and generally in inferior quality, are taken into account. The second reason is the fact that the stand has been affected by quite intense necrotic disease of beech bark (Mihál et al.. 1998; Cicák \& Mihál 2001). We explained this stem deterioration as a result of beech bark disease caused by necrosis, which also affected many crown level individuals (even target trees) and thus worsened the silvicultural quality of the stand as a whole and the crown layer, as well. Regarding the quality of crown, improvement occurred everywhere during 30 years (except for the subplot IV), where very slight deterioration was recorded.

Another situation arose with the crown quality of the crown level (target) trees, where improvement was recorded (except for subplot IV) everywhere. This is related to the concept of applied the free crown thinning, where the positive selection at the crown level is the primary goal (Štefančík 1984).

Our investigated parameters for the stem and crown quality were influenced mainly by the occurrence of necrotic disease of beech bark in the late eighties of the last century. This tracheomycosis disease weakened the stands' vitality. As a result, there had been several stem breaks on places with extensive necrosis. Detailed research on their occurrence on this PRP (Cicák et al. 1998; Mihál et al. 1998; Cicák \& Mihál 2001) proved a $97 \%$ share of trees with different degrees of necrotic disease. The lowest index of necrotic disease occurrence was observed on the subplot IV where the highest number of target trees is located. This relates to the fact that target trees had a lower proportion of trees with the necrosis (Cicák et al. 2003). That assessment was repeated later in 1996 and 2000 , i.e. at age of 50 and 54 years. The results again showed better values for the index indicating the necrotic disease of target trees in comparison to other trees in the stand (Cicák et al. 2003). Despite the fact that beech bark disease affected some target trees (Štefančík 2015), so they had to be cut from a health reasons, their current number can be considered sufficient and promising. In relation to the method of tending, the research results of a necrotic disease of beech bark found virtually no differences between the stands with thinning and stands without tending applied (Štefančík \& Leontovyč 1966; Štefančík 1974; Cicák et al. 1998; Mihál et al. 1998). However, the finding that the target trees were significantly less damaged and/or had the smallest proportion in the highest grades of damage (from $9.1 \%$ to $14.5 \%$ ), while damage amounted to $40.3 \%$ (Cicák et al. 1998) on not intervened subplots, is important. This confirms the utility of tending in such affected stands, too.

\section{Conclusion}

Comparison of four different tending variants by means of the free crown thinning was conducted for the beech stand established at the age of 38 years. Tending was performed by the method of promising (20 years) and target trees (30 years) with whole and non-whole areas approach (small growth plots). More marked differences among investigated variants did not show themselves at the stand age of 68 years (after 30 years of systematic observation). In terms of quantitative characteristics (number of trees, basal area, the merchantable volume, diameter and volume increment), slightly higher values were obtained from the variant where suppressed trees were removed from the stand at the beginning of the experiment and tending continued by the method of target trees on the whole area. Comparison of mass quality (the entire stand) did not show a beneficial effect on the stem and crown quality. One reason lies in the fact that the stand had been affected by the necrotic disease of beech bark. However, different results were obtained when comparing the stand's selective quality by means of target trees. Also, in this case, better results were achieved for the subplot IV with the mentioned variant of tending. Due to the stand age (about 70 years) and duration of investigation period (30 years), we can assume that more significant differences maybe visible in older age in favour of one of these variants. However, the longer investigation period is needed to draw objective conclusions of this experiment. On the other hand, the results presented show that rather satisfactory results can be achieved in the stand affected by the mentioned epiphytosis in terms of quantity and quality of production. Tending focused on the support of trees with selective quality (promising, target), combined with a treatment (sanitary selection and individuals affected by necrosis) in beech stands has its meaning and achieves a positive effect even in the case of beech necrotic disease.

\section{Acknowledgement}

The study was supported by the Slovak Research and Development Agency under Contract No. APVV-0262-11, APVV-060810 and $A P V V-15-0032$, as well as by the project "Research and development for innovation and support of competitiveness of forestry sector - VIPLES" funded by Ministry of Agriculture and Rural Development of the Slovak Republic.

\section{References}

Abetz, P., 1979: Brauchen wir „Durchforstungshilfen?". Schweizerische Zeitschrift für Forstwesen, 130:945-963.

Altherr, E., 1971: Wege zur Buchenstarkholzproduktion. Festschrift zur 15. Hauptversammlung des Bad. - Württ. Forst-vereins und 100-Jahr-Feier der Bad. - Württ. Forstl. Vers. - Anst., Feiburg:123-127. 
Altherr, E., 1981: Erfahrungen bei der Anwendung quantifizierter Durchforstungshilfen in Buchen beständen. Allgemeine Forstzeitschrift, 22:552-554.

Assmann, E., 1968: Náuka o výnose lesa. Bratislava, Príroda, $488 \mathrm{p}$.

Badoux, E., 1939: De l'influence de divers modes et degres d'eclaircie dans les hetraies pures. Mitteilungen der Schweizerischen Anstalt für das forstliche Versuchswesen, 21:59-146.

Barna, M., Kulfan, J., Bublinec, E. (eds.), 2011: Buk a bukové ekosystémy Slovenska. Bratislava, Veda, $636 \mathrm{p}$.

Boncina, A., 2011: History, current status and future prospects of uneven-aged forest management in the Dynaric region: an overview. Forestry, 84:467-478.

Boncina, A., Kadunc, A., Robic, D., 2007: Effects of selective thinning on growth and development of beech (Fagus sylvatica L.) forest stands in southeastern Slovenia. Annals of Forest Science, 64:47-57.

Bouchon, J., Dhôte. J. F., Lanier, L., 1989: Réaction individuelle de hêtres (Fagus syslvatica L.) d'âges divers à diverses intensités d'éclaircie. Annals Science Forestry, 46:251-259.

Cameron, A. D., 2002: Importance of early selective thinning in the development of long-term stand stability and improved log quality: a review. Forestry, 75:25-35.

Cicák, A., Mihál, I., Štefančík, I., 1998: Health condition, bark necrosis and mycoflora in a pure beech pole-stage stand. Lesnictví - Forestry, 44:49-57.

Cicák, A., Mihál, I., 2001:T-disease-a little investigated phenomenon of the beech (Fagus sylvatica L.) necrotic damage. Journal of Forest Science, 47:38-41.

Cicák, A., Mihál, I., Štefančík, I., 2003: Development of necrotic disease and health of trees of selective quality in a systematically tended beech pole-stage stand. Journal of Forest Science, 49:11-18.

Diaci, J., Kerr, G., O’Hara, K., 2011: Twenty-first century forestry: integrating ecologically based, uneven-aged silviculture with increasing demands on forests. Forestry, 84:463-465.

Diaconu, D., Kahle, H. P., Spiecker, H., 2015: Tree- and Stand-Level Thinning Effects on Growth of European Beech (Fagus sylvatica L.) on a Nordeast- and a Southwest-facing Slope in Southwest Germany. Forests, 6: 3256-3277.

Dhôte, J. F., 1997: Effets des éclaircies sur le diametre dominant dans des futaies regulieres de hetre ou de chene sessile. Revue Forestière Française, 49:557578.

Ducros, E. T., Thiebaut, B., Duval, H., 1988: Variability in beech - budding, height growth and tree form. Annales des Sciences Forestieres, 45:383-398.

Fabrika, M., 2005: Návrh algoritmov pre prebierkový model rastového simulátora SIBYLA. Lesnícky časopis - Forestry Journal, 51:145-170.
Ferrand, J. C., 1982: Variabilité en forêt des contraintes de croissance du hêtre (Fagus sylvatica L.). Annals of Forest Science, 39:187-218.

Fichtner, A., Sturm, K., Rickert, C., von Oheimb, G., Härdtle, W., 2013: Crown size-growth relationships of European beech (Fagus sylvatica L.) are driven by the interplay of disturbance intensity and inter-specific competition. Forest Ecology and Management, 302:178-184.

Foerster, W., 1993: Der Buchen-Durchforstungsversuch Mittelsinn 025. Allgemeine Forst Zeitschrift, 48:268-270.

Freist, H., 1962: Untersuchungen über den Lichtungszuwachs der Rotbuche und seine Ausnutzung im Forstbetrieb. Beihefte zum Forstwissen Centralblatt, $78 \mathrm{p}$.

Füldner, K., 1995: Strukturbeschreibung in Mischbeständen. Forstarchiv, 66:235-240.

Gömöry, D., Paule, L., 2011: Trade-off between height growth and spring flushing in common beech (Fagus sylvatica L.). Annals of Forest Science, 68:975-984.

Gömöry, D., Comps, B., Paule, L., von Wühlisch, G., 2013: Allozyme and phenotypic variation in beech (Fagus sylvatica L.): are there any links? Plant Biosystems, 147:265-271.

Guericke, M., 2002: Untersuchungen zur Wuchsdynamik der Buche. Forst und Holz, 57:331-337.

Hansen, J. K, Jorgensen, B. B, Stoltze, P., 2003: Variation of quality and predicted economic returns between European beech (Fagus sylvatica L.) provenances. Silvae Genetica, 52:185-197.

Hein, S., Lenk, E., Klädtke, J., Kohnle, U., 2007: Effect of crop tree selective thinning on beech (Fagus sylvatica L.). Allgemeine Forst- und Jagdzeitung, 178:8-20.

Hoffmann, R, 1994: The selective and selection principle in beech. Allgemeine Forst Zeitschrift, 49:11001103.

Chunyu Zhang, Ch., Petráš, R., Zhao, X., von Gadow, K., 2010: Estimating Beech Growth and Survival. A study based on long-term experiments in Slovakia. Allgemeine Forst- und Jagdzeitung, 181:45-52.

Jullien, D., Widmann, R., Loup, C., Thibaut, B., 2013: Relationship between tree morphology and growth stress in mature European beech stands. Annals of Forest Science, 70:133-142.

Jurča, J., Chroust, L., 1973: Racionalizace výchovy mladých lesních porostů. Praha, SZN, 239 p.

Kató, F., Mülder, D., 1983: Qualitative Gruppendurchforstung der Buche. Allgemeine Forst- und Jagdzeitung, 154:139-145.

Keller, R., Le Tacon, F., Timbal, J., 1976: La densité du bois de hêtre dans le nord-est de la France. Influence des caractéristiques du milieu et du type de sylviculture. Annals of Forest Science, 33:1-17.

Kennel, R., 1972: Die Buchendurchforstungsversuche in Bayern von 1870 bis 1970 . Forstliche Forschungsberichte München, 7:264 p. 
Klädtke, J., 1997: Buchen-Lichtwuchsdurchforstung. Allgemeine Forst-Zeitschrift, 52:1019-1023.

Klädtke, J., 2002: Growth of beeches with large crowns and consequences for silviculture. Forstarchiv, 73:211-217.

Knoke, Th., Wenderoth, S. S., 2001: Ein Ansatz zur Beschreibumg von Wahrscheinlichkeit und Ausmaß der Farbkernbildung bei Buche (Fagus sylvatica L.). Forstwissenschaftliches Centralblatt, 120:154-172.

Korpel', Š., 1988: Dynamika rastu a vývoja bukových porastov vo fáze mladiny až žrd'oviny vplyvom pestovnej techniky. Acta Facultatis Forestalis Zvolen, 30:9-38.

Kramer, H., 1988: Waldwachstumslehre. Hamburg, Berlin, Paul Parey.

Kupka, K., 2008: QC.Expert, ADSTAT. User's manual, TryloByte, Ltd., Pardubice, 168 p.

Kurt, A., 1982: Ziel, Voraussage und Kontrolle von Nutzungen im Forstbetrieb. Schweizerische Zeitschrift für Forstwesen, 133:93-114.

LeGoff, N., Ottorini, J. M., 1993: Thinning and climate effects on growth of beech (Fagus sylvatica L.) in experimental stands. Forest Ecology and Management, 62:1-14.

Leibundgut, H., 1966: Die Waldpflege. Bern, Verlag P. Haupt, 312 p.

Leibundgut, H., 1982: Über die Anzahl Auslesebäume bei der Auslesedurchforstung. Schweizerische Zeitschrift für Forstwesen, 133:115-119.

Merganič, J., Merganičová, K., Marušák, R., Tipmann, L., Śálek, L., Dragoun, L., Stolariková, R., 2016: Relation between selected indicators of forest stand diversity and quality of timber production on managed Central European forests. Journal of Forest Science, 62:97-106.

Mihál, I., Cicák, A., Štefančík, I., 1998: Health condition and bark necrotic disease of trees of selective quality in a systematically tended beech pole-stage stand. Lesnictví - Forestry, 44:97-102.

Michailoff, I., 1943: Zahlenmässiges Verfahren für die Ausführung der Bestandeshöhenkurven. Forstwissenschaftliches Centralblatt und Tharandter Forstliches Jahrbuch, 6:273-279.

Mlinšek, D., Bakker, A., 1990: Jugendwachstum und Holzqualität bei der Buche. Forstwissenschaftliches Centralblatt, 109:242-248.

Pardé, J., 1981: De 1882 á 1976/80 les places d'expérience de sylviculture du hêtre en forêt domaniale de Haye. Revue Forestière Française, 33:41-64.

Petráš, R., Pajtík, J., 1991: Sústava česko-slovenských objemových tabuliek drevín. Lesnícky časopis, 37:49-56.

Petráš, R., Mecko, J., 2010: Stability of the development of basic stand parameters of beech yield tables constructed on the basis of short-term observations on research plots. Journal of Forest Science, 56:323332.
Petráš, R., Mecko, J., Bošel'a, M., Šebeň, V., 2016:Wood quality and value production in mixed fir-sprucebeech stands: long-term research in the Western Carpathians. Lesnícky časopis - Forestry Journal, 62: 98-104.

Poleno, Z., Vacek, S. et al., 2009: Pěstování lesů III. Praktické postupy pěstování lesů. Lesnická práce, 952 p.

Polge, H., 1981: Influence des éclaircies sur les contraintes de croissance du hêtre. Annals of Forest Science, 38:407-423.

Poljanec, A., Kadunc, A., 2013: Quality and timber value of European beech (Fagus sylvatica L.) trees in the Karavanke region. Croatian Journal of Forest Engineering, 34: 151-165.

Pretzsch, H., 2005: Stand density and growth of Norway spruce (Picea abies (L.) Karst.) and European beech (Fagus sylvatica L.): evidence from long-term experimental plots. European Journal of Forest Research, 124:193-205.

Pretzsch, H., Biber, P., Schütze, G., Uhl, E., Rötzer, T., 2014: Forest stand growth dynamics in Central Europe have accelerated since 1870. Nature Communications, 5:4967.

Priesol, A., Polák, L., 1991: Hospodárska úprava lesov. Bratislava, Príroda, 448 p.

Réh, J., 1968: Štúdium štruktúry bukovej húštiny. Lesnícky časopis, 14:651-671.

Réh, J., 1969: Príspevok k poznaniu vývoja a niektorých morfologických znakov buka v húštinách. Zborník vedeckých prác LF VŠLD vo Zvolene, XI:67-82.

Réh, J., 2004: Vplyv systematickej a omeškanej výchovy na kvantitatívnu a kvalitatívnu produkciu bukových žrd'ovín. Lesnícky časopis - Forestry Journal, 50:161-182.

Saje, R., Pajk, B., Kadunc, A., Bončina, A., 2013: Beech thinning experiment in the research objects Pišice and Brezova reber. Gozdarski Vestnik, 71:387-401.

Sedmák, R., Scheer, L., Melcerová,A. 2012: Návrh a validácia matematického modelu zmien kvality stromov a porastov. Lesnícky časopis - Forestry Journal, 58:92-99.

Schädelin, W., 1934: Die Durchforstung als Auslese- und Veredelungsbetrieb höchster Wertleistung. Bern Leipzig: Verlag Haupt, 198 p.

Spellmann, H., Nagel, J., 1996: Zur Durchforstung von Fichte und Buche. Allgemeine Forst und Jagdzeitung, 167:6-15.

Šebík, L., 1970: Kvalita a vplyv prvých úrovňových prebierok na kvalitu predrubných bukových porastov. Zborník vedeckých prác LF VŠLD vo Zvolene, 12:31-50.

Šebík, L., 1971: Vplyv miernej podúrovňovej a akostovej úrovňovej prebierky na štruktúru a produkciu predrubných bukových porastov.Zborník vedeckých prác LF VŠLD vo Zvolene, 13:63-91.

Šebík, L., Polák, L., 1990: Náuka o produkcii dreva. Bratislava, Príroda, 322 p. 
Štefančík, I., 2013: Development of target (crop) trees in beech (Fagus sylvatica L.) stand with delayed initial tending and managed by different thinning methods. Journal of Forest Science, 59:253-259.

Štefančík, I., 2013a: Effect of delayed tending on development of beech (Fagus sylvatica L.) pole stage stand. Folia Oecologica, 40:272-281.

Štefančík, I., 2014: Porovnanie kvalitatívnej produkcie dvoch bukových (Fagus sylvatica L.) porastov na kyslom stanovišti. Lesnícky časopis - Forestry Journal, 60:231-239.

Štefančík, I., 2015: Rast, štruktúra a produkcia bukových porastov s rozdielnym režimom výchovy. Zvolen, NLC-LVÚ, 148 p.

Štefančík, I., Bošela, M., 2014: An influence of different thinning methods on qualitative wood production of European beech (Fagus sylvatica L.) on two eutrophic sites in the Western Carpathians. Journal of Forest Science, 60:406-416.

Štefančík, L., 1964: K histórii prebierok na Slovensku. Vedecké práce VÚLH v Banskej Štiavnici, Bratislava, SVPL, 5:107-130.

Štefančík, L., 1974: Prebierky bukových žrdovín. Lesnícke štúdie, Bratislava, Príroda, 18:141 p.

Štefančík, L., 1975: Pestovanie akostnej produkciev vukových porastoch. Lesnictví, 21:749-766.

Štefančík, L., 1976: Hromadná kvalita bukového porastu a jej zmeny vplyvom prirodzeného vývoja a prebierky. Lesnícky časopis, 22:141-157.

Štefančík, L., 1981:Vplyv prebierok na výberovú kvalitu $\mathrm{v}$ pestovne zanedbaných bukových porastoch. Lesnictví, 27:525-533.

Štefančík, L., 1984: Úrovňová voliná prebierka - metóda biologickej intenzifikácie a racionalizácie selekčnej výchovy bukových porastov. Vedecké práce VÚLH vo Zvolene, 34:69-112.

Štefančík, L., Leontovyč, R., 1966: O nekróze kôry miazgotoku buka na východnom Slovensku. Lesnícky časopis, 12:521-532.
Štefančík, L., Utschig, H., Pretzsch, H., 1996: Paralelné sledovanie rastu a štruktúry nezmiešaného bukového porastu na dlhodobých prebierkových výskumných plochách v Bavorsku a na Slovensku. Lesnictví - Forestry, 42:3-19.

Tufekcioglu, A., Guner, S., Tilki, F., 2005: Thinning effects on production, root biomass and some soil properties in a young oriental beech stand in Artvin, Turkey. Journal of Environmental Biology, 26:91-95.

Utschig, H., 2000: Wachstum vorherrschender Buchen in Abhängigkeit von Standort und Behandlung. Forst und Holz, 55:44-50.

Utschig, H., Küsters, E., 2003: Growth reactions of common beech (Fagus sylvatica L.) related to thinning -130 years observation of the thinning experiment Elmstein 20. Forstwissenschaftliches Centralblatt, 122:389-409.

Vacek, S., Chroust, L., Souček, J., 1996: Produkční analýza autochtonních bučin. Lesnictví, 43:54-66.

Vacek, S., Hejcman, M., 2012: Natural layering, foliation, fertility and plant species composition of a Fagus sylvatica stand above the alpine timberline in the Giant (Krkonoše) Mts., Czech Republic. European Journal of Forest Research, 131:799-810.

Vacek, S., Vacek, Z., Podrazský, V., Bilek, L., Bulušek, D., Štefančík, I. et al., 2014: Structural Diversity of Autochthonous Beech Forests in Broumovske Stěny National Nature Reserve, Czech Republic. Austrian Journal of Forest Science, 131:191-214.

Vladovič, J., 2003: Oblastné východiská a princípy hodnotenia drevinového zloženia a ekologickej stability lesov Slovenska. Lesnícke štúdie, Bratislava, Príroda, $57: 160 \mathrm{p}$.

von Lüpke, B., 1986: Thinning, especially early thinning, of pure beech stands. Forst und Holzwirtschaft, 41:54-61.

Vyskot, M. et al., 1962: Probírky (biotechnika a efektivnost). Praha, SZN, $301 \mathrm{p}$.

Zelená správa, 2015: Správa o lesnom hospodárstve v Slovenskej republike za rok 2014. Bratislava, MP RV SR, 83 p. 